STANDARDIZED VERSUS INDIVIDUALIZED PARENTERAL NUTRITION IN VERY-LOWBIRTH-WEIGHT INFANTS: A COMPARATIVE STUDY

T. Smolkin ${ }^{1}$, G. Diab ${ }^{2}$, I. Shohat ${ }^{2}$, H. Jubran ${ }^{1}$, S. Blazer ${ }^{1}$, G.S. Rozen ${ }^{2}$, I.R. Makhoul ${ }^{1}$

${ }^{1}$ Neonatology, ${ }^{2}$ Clinical Nutrition, Rambam Medical Center, Haifa, Israel

Background: Parenteral nutrition (PN) improves growth and outcome of very-low-birth-weight (VLBW) infants. Optimal PN composition, standard (STD-PN) or individualized (IND-PN), is still controversial.

Aim: To compare IND-PN and STD-PN as to nutritional and growth parameters, complications and cost.

Patients and methods: 140 VLBW infants were studied. Each of the 70 neonates from the INDPN group was matched with a neonate of similar gestational age (GA) ( \pm 4 days) on STD-PN. Data collection included demographic, maternal, intrapartum, neonatal, interventional, growth and nutritional data.

Results: Compared to STD-PN infants, INDPN infants had a significantly lower mean birth weight, greater need for resuscitation at birth and interventions thereafter. Nevertheless, IND-PN infants showed significantly greater weight-gain SDS during the 1 st week $(p=0.036)$ and the 1 st month of life $(p=0.0004)$, and higher dischargeweight SDS $(p=0.012)$ and head-circumference SDS $(p=0.006)$. IND-PN infants received higher mean daily caloric intakes. They also had significantly shorter durations of exclusive PN and needed less electrolyte corrections.

Conclusions: Compared to STD-PN infants, INDPN infants achieved significantly better growth without added clinical or laboratory complications, had shorter period of exclusive $\mathrm{PN}$ and less electrolyte corrections. IND-PN, in accordance with the current more aggressive nutritional approach, appears optimal for PN of VLBW infants. Yet, STD$\mathrm{PN}$ with adequate composition is an appropriate alternative.
1020

\section{SURVEY OF INTRAVENOUS(IV) FLUID MANAGEMENT ON THE NEONATAL UNITS IN THE UNITED KINGDOM(UK)}

K. Yerur Vrajananda, P. Desai

2nd Department of Paediatrics, Ipswich Hospital, Ipswich, UK

Aims and methodology: Questionnaires were emailed to the neonatologists across the UK. The questions included the volumes of IV fluids administered in term and preterm babies, any variations made for extreme preterm babies, babies receiving phototherapy, and at risk of hypoxic ischemic encephalopathy(HIE).

Results: Valid responses were obtained from 111 neonatal units. The volumes of IV fluids administered are tabulated.

\begin{tabular}{|l|l|l|l|l|l|l|}
\hline $\begin{array}{l}\text { Mean IV } \\
\text { fluids }\end{array}$ & $\begin{array}{l}\text { Mean } \\
\text { volume } \\
\text { in } \mathrm{ml} / \\
\mathrm{kg} / \mathrm{day}\end{array}$ & $\begin{array}{l}\text { DAY } \\
1(\mathrm{ml} / \\
\mathrm{kg} / \\
\text { day })\end{array}$ & $\begin{array}{l}\text { DAY } \\
2(\mathrm{ml} / \\
\mathrm{kg} / \\
\text { day })\end{array}$ & $\begin{array}{l}\text { DAY } \\
3(\mathrm{ml} / \\
\mathrm{kg} / \\
\text { day })\end{array}$ & $\begin{array}{l}\text { DAY } \\
4(\mathrm{ml} / \\
\mathrm{kg} / \\
\text { day })\end{array}$ & $\begin{array}{l}\text { DAY } \\
5(\mathrm{ml} / \\
\mathrm{kg} / \\
\text { day })\end{array}$ \\
\hline $\begin{array}{l}\text { Level 1 } \\
\text { neonatal } \\
\text { units } \\
(\mathrm{n}=18)\end{array}$ & $\begin{array}{l}\text { Term } \\
\text { babies }\end{array}$ & 58.6 & 84.7 & 110.3 & 136.5 & 146.1 \\
\hline & $\begin{array}{l}\text { Preterm } \\
\text { babies }\end{array}$ & 65.3 & 93.5 & 121.2 & 144.4 & 152 \\
\hline $\begin{array}{l}\text { Level } \\
2(\mathrm{n}=57)\end{array}$ & $\begin{array}{l}\text { Term } \\
\text { babies }\end{array}$ & 58.9 & 85.7 & 112.6 & 139 & 148.3 \\
\hline $\begin{array}{l}\text { Preterm } \\
\text { babies }\end{array}$ & 68 & 95.1 & 121.7 & 144.9 & 151.8 \\
\hline $\begin{array}{l}\text { Level } \\
3(\mathrm{n}=36)\end{array}$ & $\begin{array}{l}\text { Term } \\
\text { babies }\end{array}$ & 62.2 & 85.7 & 109.7 & 134.4 & 145.7 \\
\hline & $\begin{array}{l}\text { Preterm } \\
\text { babies }\end{array}$ & 76.9 & 100.7 & 125.2 & 142.7 & 149.6 \\
\hline
\end{tabular}

[Term and preterm babies]

\begin{tabular}{|l|l|l|l|}
\hline $\begin{array}{l}\text { Number of } \\
\text { units (\%) }\end{array}$ & $\begin{array}{l}\text { Extra fluids } \\
\text { for babies } \\
\text { less than } \\
1 \mathrm{~kg}\end{array}$ & $\begin{array}{l}\text { Extra fluids } \\
\text { for babies on } \\
\text { phototherapy }\end{array}$ & $\begin{array}{l}\text { Restricting } \\
\text { fluids for } \\
\text { babies at } \\
\text { risk of HIE }\end{array}$ \\
\hline $\begin{array}{l}\text { Level 1 } \\
\text { neonatal } \\
\text { units }\end{array}$ & $\begin{array}{l}6 / 18 \\
(33.3 \%)\end{array}$ & $11 / 18(61.1 \%)$ & $\begin{array}{l}15 / 18 \\
(83.3 \%)\end{array}$ \\
\hline $\begin{array}{l}\text { Level 2 } \\
\text { neonatal } \\
\text { units }\end{array}$ & $\begin{array}{l}25 / 57 \\
(43.8 \%)\end{array}$ & $25 / 57(43.8 \%)$ & $\begin{array}{l}54 / 57 \\
(94.7 \%)\end{array}$ \\
\hline $\begin{array}{l}\text { Level 3 } \\
\text { neonatal } \\
\text { units }\end{array}$ & $\begin{array}{l}17 / 36 \\
(47.2 \%)\end{array}$ & $7 / 36(19.4 \%)$ & $\begin{array}{l}29 / 36 \\
(80.5 \%)\end{array}$ \\
\hline
\end{tabular}

[Additional questions] 
Conclusions: The practice of fluid administration follows similar trends across UK, with slight differences. The tertiary level 3 units are more liberal with their fluids, especially for preterm babies. Most units restrict IV fluids for babies at risk of HIE. There is a variation in practice in terms of liberalizing fluids for extreme preterms and babies on phototherapy. This study highlights the dilemma faced by neonatologists in the fluid management, mainly due to multiple variables influencing fluid balance in the newborn.

\section{1}

\section{BONE STRENGTH MEASURED BY QUANTITATIVE ULTRASOUND IN NEWBORN INFANTS IN TAIWAN}

\author{
H.-L. Chen, H.-I. Tseng, C.-C. Lu, S.-N. Yang,
} R.-C. Yang

Pediatrics, Kaohsiung Medical University Hospital, Kaohisung, Taiwan R.O.C.

Background and aims: The measurement of speed of sound (SOS) by quantitative ultrasound could be used to assess bone strength in newborn infants. There is few data about bone strength in newborn infants in Taiwan. Our objective was to determine the bone strength measured by SOS of newborns in Taiwan and also to evaluate the factors associated with bone strength at birth.

Methods: Full term and preterm infants admitted to baby room or neonatal ward of Kaohsiung Medical University Hospital were enrolled. Birth chart and maternal history were recorded. SOS measured by quantitative ultrasonography was performed at the left tibia in one week after birth.

Results: A total of 513 infants were enrolled in this study. For term infants (more than 37 weeks), mean SOS was $2964.8 \mathrm{~m} / \mathrm{s}$ (SD $104.1 \mathrm{~m} / \mathrm{s}$ ), which significantly higher than infants with gestational age 32-36 weeks (mean \pm SD, $2951.6 \pm 99.9 \mathrm{~m} / \mathrm{s}$ ) and gestational age less than 32 weeks (2867.2 \pm 123.7 $\mathrm{m} / \mathrm{s}$ ). In all infants, there was a significant positive correlation between SOS and gestational age, birth weight, birth length, and head circumference. Male babies had higher SOS than female babies $(p=0.004)$. Multiple regression analysis revealed gender, gestational age and birth weight were two important factors influencing SOS at birth. The procedure was well tolerated in all infants. No adverse effects were found.
Conclusions: Bone strength measured by quantitative ultrasound in newborn infants are correlated with gender, gestational age and birth anthropometrics, but not related to maternal factors, and seasons of birth.

\section{2}

\section{LONG-TERM OUTCOME IN CHILDREN WITH METABOLIC ENCEPHALOPATHY TREATED WITH EARLY CONTINUOUS VENO-VENOUS HEMODIAFILTRATION}

\author{
M. Corno ${ }^{1}$, C. Barbanti ${ }^{1}$, S. Vedovati ${ }^{1}$, R. Parini ${ }^{2}$, \\ D. Codazzi ${ }^{1}$ \\ ${ }^{1}$ PICU - Ospedali Riuniti di Bergamo, Bergamo, \\ ${ }^{2}$ Unit for Rare Metabolic Diseases, Department of \\ Pediatrics, San Gerardo Hospital, Monza, Italy
}

Aims: To suggest an intensive treatment in children with inborn errors of metabolism; to describe the early use of continuous veno-venous hemodiafiltration for life-threatening hyperammonemic encephalopathy.

Design: Retrospective analysis of children with inborn errors of metabolism (IEMs) that can produce acute pathologic states, characterized by metabolic encephalopathy, hyperammonemia, hemodynamic collapse and alterations in acid-base equilibrium, that range from mild to lethal.

Patients: 8 children with IEM-related metabolic disturbances admitted to our pediatric intensive care unit from July 12004 to October 302006 who underwent continuous veno-venous hemodiafiltration (CVVH), and a two year follow-up of these selected patients with the aim of seeing the number of relapses, physical development and neurological outcome. In addition we reviewed how these patients have been treated in the acute phase of decompensation.

Results: Eight patients were eligible for review. No patient had a definite diagnosis of disease at admission. All patients were transferred to our unit from peripheral hospitals: delay from suspected diagnosis to the start of depuration therapy ranged from 8 to 48 hours, with a duration of coma ranging from 3 to 36 hours. Time to start dialysis upon admission was within 2 hours. Two patients died. The six patients surviving the first episode had a good neurologic outcome according to the Bailey Scale of Infant Development.

Conclusion: Patients with IEM surviving their first decompensation had a good neurologic follow-up. 